\title{
Malonyl CoenzymeA Decarboxylase Regulates Lipid and Glucose Metabolism in Human Skeletal Muscle
}

\author{
Karim Bouzakri, ${ }^{1}$ Reginald Austin, ${ }^{1}$ Anna Rune, ${ }^{1}$ Michael E. Lassman, ${ }^{2}$ Pablo M. Garcia-Roves, ${ }^{1}$ \\ Joel P. Berger, ${ }^{2}$ Anna Krook, ${ }^{1,3}$ Alexander V. Chibalin, ${ }^{1}$ Bei B. Zhang, ${ }^{2}$ and Juleen R. Zierath ${ }^{1}$
}

\begin{abstract}
OBJECTIVE-Malonyl coenzyme A (CoA) decarboxylase (MCD) is a key enzyme responsible for malonyl-CoA turnover and functions in the control of the balance between lipid and glucose metabolism. We utilized RNA interference (siRNA)based gene silencing to determine the direct role of MCD on metabolic responses in primary human skeletal muscle.
\end{abstract}

RESEARCH DESIGN AND METHODS-We used siRNA to silence MCD gene expression in cultured human myotubes from healthy volunteers (seven male and seven female) with no known metabolic disorders. Thereafter, we determined lipid and glucose metabolism and signal transduction under basal and insulinstimulated conditions.

RESULTS-RNA interference-based silencing of MCD expression (75\% reduction) increased malonyl-CoA levels twofold and shifted substrate utilization from lipid to glucose oxidation. RNA interference-based depletion of MCD reduced basal palmitate oxidation. In parallel with this reduction, palmitate uptake was decreased under basal (40\%) and insulin-stimulated (49\%) conditions compared with myotubes transfected with a scrambled sequence. MCD silencing increased basal and insulin-mediated glucose oxidation 1.4- and 2.6-fold, respectively, compared with myotubes transfected with a scrambled sequence. In addition, glucose transport and cell-surface GLUT4 content was increased. In contrast, insulin action on IRS-1 tyrosine phosphorylation, tyrosine-associated phosphatidylinositol (PI) 3-kinase activity, Akt, and glycogen synthase kinase (GSK) phosphorylation was unaltered between myotubes transfected with siRNA against MCD versus a scrambled sequence.

CONCLUSIONS-These results provide evidence that MCD silencing suppresses lipid uptake and enhances glucose uptake in primary human myotubes. In conclusion, MCD expression plays a key reciprocal role in the balance between lipid and glucose metabolism. Diabetes 57:1508-1516, 2008

From the ${ }^{1}$ Department of Molecular Medicine and Surgery, Karolinska University Hospital, Karolinska Institutet, Stockholm, Sweden; ${ }^{2}$ Merck Research Laboratories, Rahway, NJ; and the ${ }^{3}$ Department of Physiology and Pharmacology, Karolinska Institutet, Stockholm, Sweden.

Corresponding author: Prof. Juleen R. Zierath, Karolinska Institutet, Department of Molecular Medicine and Surgery, Section of Integrative Physiology, von Eulers väg 4, 4th floor, S-171 77 Stockholm, Sweden. E-mail: juleen.zierath@ki.se.

Received for publication 27 April 2007 and accepted in revised form 18 February 2008.

Published ahead of print at http://diabetes.diabetesjournals.org on $25 \mathrm{Feb}-$ ruary 2008. DOI: $10.2337 / \mathrm{db} 07-0583$.

K.B. and R.A. contributed equally to this work

M.E.L., J.B., and B.Z. are employees and shareholders of Merck.

ACC, acetyl-CoA carboxylase; AMPK, AMP-activated protein kinase; CoA, coenzyme A; CPT-1, carnitine palmitoyl transferase 1; DAG, diacylglycerol; DMEM, Dulbecco's modified Eagle's medium; FATP, fatty acid transport protein; GSK, glycogen synthase kinase; LCFA, long-chain fatty acid; MCD, malonyl-CoA decarboxylase; LCFA, long chain fatty acids; PBS, phosphatebuffered saline; PDK, pyruvate dehydrogenase kinase; PI, phosphatidylinositol; TBST, Tris-buffered saline plus Tween.

(C) 2008 by the American Diabetes Association.

The costs of publication of this article were defrayed in part by the payment of page charges. This article must therefore be hereby marked "advertisement" in accordance with 18 U.S.C. Section 1734 solely to indicate this fact.

See accompanying commentary, p. 1455.

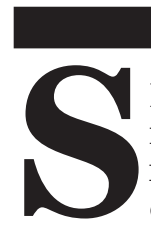
keletal muscle plays a vital role in whole-body insulin-mediated glucose metabolism, with the flux of intramyocellular fatty acids to lipogenesis or oxidation impacting on glucose disposal. In humans, intramyocellular lipid levels of skeletal muscle are inversely correlated with whole-body insulin sensitivity (1). Increasing evidence suggests that extensive triacylglycerol accumulation in skeletal muscle (i.e., ectopic fat deposition) impairs insulin signaling and glucose uptake and contributes to an intracellular energy imbalance characteristic of type 2 diabetes and other metabolic diseases (2-5). Dysregulation of the malonyl coenzyme A (CoA) signaling mechanism has been proposed to contribute to the development of lipid abnormalities in metabolic disease (6).

In lipogenic tissues such as liver and adipose tissue, malonyl-CoA is the first intermediate regulator in the synthesis of long-chain fatty acids (LCFAs). Malonyl-CoA allosterically binds to carnitine palmitoyl transferase 1 (CPT-1), thereby inhibiting the enzyme and the transfer of LCFA into the mitochondria (7). In nonlipogenic tissues, such as cardiac and skeletal muscle, malonyl-CoA plays a role in the control of intracellular energy balance by inhibiting CPT-1 and reducing LCFA oxidation and/or reesterification into triglycerides $(8,9)$.

AMP-activated protein kinase (AMPK), an enzyme that increases skeletal muscle fatty acid oxidation and insulin sensitivity (10), is intimately linked to the malonyl-CoA signaling mechanism (6). In mice lacking the AMPK substrate acetyl-CoA carboxylase (ACC) 2 and thus having reduced malonyl-CoA levels, lipid oxidation is elevated and lipid storage is reduced, suggesting that ACC and malonyl-CoA play an important role in overall energy balance (11).

AMPK modulates the concentration of malonyl-CoA by concurrently phosphorylating and inhibiting ACC, the ratelimiting enzyme in malonyl-CoA synthesis, and phosphorylating and activating malonyl-CoA decarboxylase (MCD) $(6,12)$. Thus, malonyl-CoA is produced by ACC and catabolized by MCD. In skeletal muscle, changes in fuel availability and energy expenditure influence malonyl-CoA concentration (13), presumably via reciprocal regulation between AMPK and MCD (14). For example, malonyl-CoA levels are increased in insulin-resistant tissues (15) and reduced after exercise (16).

Whether MCD expression directly contributes to changes in the uptake and oxidation of metabolic substrates in skeletal muscle is unknown. Whole-body MCD knockdown protects against the development of dietaryinduced insulin resistance (17), but the tissue-specific mechanism(s) is unresolved since MCD plays a metabolic role in multiple organs responsible for whole-body glucose 
and energy homeostasis $(18,19)$. Recent studies performed in mice demonstrated that MCD deletion in heart markedly increases glucose oxidation and improves functional recovery after ischemia (20). Moreover, MCD overexpression in hypothalamus decreases LCFA and blunts the hypothalamic responses to increased lipid availability, thereby increasing food intake (21). Thus, MCD appears to play a central role in regulating malonyl-CoA content and fatty acid oxidation.

Here, we determined the direct role of MCD on glucose and lipid metabolism in primary human skeletal muscle myotubes by RNA interference-mediated (siRNA) gene silencing. Molecular disruption of MCD altered substrate utilization in skeletal muscle, as evidenced by decreased lipid oxidation and increased glucose uptake and oxidation. MCD appears to play a pivotal role in the metabolic balance between glucose and lipid oxidation in skeletal muscle.

\section{RESEARCH DESIGN AND METHODS}

Dulbecco's modified Eagle's medium (DMEM), Ham's F-10 medium, fetal bovine serum, penicillin, streptomycin, and fungizone were obtained from GibcoBRL (Invitrogen, Stockholm, Sweden). Unless specified, the reagents used in this study were obtained from Sigma. Radioactive reagents were purchased from Amersham.

Skeletal muscle biopsies (rectus abdominus or vastus lateralis) were obtained with the informed consent of the donors during scheduled abdominal surgery or through needle biopsy, respectively. Subjects (seven male and seven female) had no known metabolic disorders. Mean age was $61 \pm 5$ years $\left(\mathrm{BMI}<26 \mathrm{~kg} / \mathrm{m}^{2}\right)$. The ethics committee at Karolinska Institutet approved the study protocols. Satellite cells were isolated from muscle biopsies by trypsin digestion and grown to confluent myoblasts that were differentiated into myotubes as described $(22,23)$.

siRNA transfection in myotubes. Myotubes were transfected using Lipofectamine 2000 (Invitrogen). Differentiation media was changed to antibioticfree growth media on day 2 of myotube differentiation protocol. On day 3 , myotubes were transfected with individual siRNAs $(1 \mu \mathrm{g} / \mathrm{ml})$ using Lipofectamine 2000 in serum-free DMEM (incubation time $>16 \mathrm{~h}$ ). Pools of four siRNA sequences directed against MCD or a scrambled sequence were used. siRNA oligos for MCD were purchased from Dharmacon (Chicago, IL). Myotubes were then washed with phosphate-buffered saline (PBS), and $2 \mathrm{ml}$ DMEM containing $2 \%$ fetal bovine serum was added to each well. On day 6 of differentiation protocol, the cells were deprived of serum for $16 \mathrm{~h}$ before further incubation in the absence or presence of insulin $(120 \mathrm{nmol} / \mathrm{l})$. Control cultures were prepared without addition of MCD siRNA (control) or scrambled siRNA (24).

Analysis of mRNA expression. Myotubes prepared as described above were washed three times with RNase-free PBS and then harvested directly for RNA extraction (RNAeasy minikit; Qiagen). All RNA was DNase-treated before reverse transcription (RQ1 RNase-free DNase; Promega). Total RNA concentration was measured and reverse transcribed with oligo (dT) primers using the SuperScript First Strand Synthesis System (Invitrogen). Reactions were performed in duplicate in a 96-well format using a Prism 7000 Sequence Detector and TaqMan-based technology (Applied Biosystems). Oligonucleotide primers (sequences available on request) and TaqMan probes were purchased from Applied Biosystems. Relative quantities of target transcripts were calculated after normalization of the data using the standard curve method.

Quantitation of malonyl-CoA, acetyl-CoA, CoASH, diacylglycerol (DAG), and ceramide content. Myotubes prepared as described above were lysed in $10 \%$ sulfosalicylic acid with $10 \mathrm{mmol} / \mathrm{l}$ dithiothreitol. The lysates were spun at $15,000 \mathrm{~g}$ and the supernate analyzed by liquid chromatography-mass spectrometry without dilution or sample treatment. An Agilent 1100 series capillary pump (Wilmington, DE) was interfaced with an LTQ ion trap mass spectrometer (Thermo Fisher Scientific, San Jose, CA). The methodology used was a modification of that reported by Minkler et al. (25). Analyte concentrations were calculated by comparing the signal from triplicate injections to that of a standard curve acquired both immediately before and after the sample queue. DAG and ceramide content in human skeletal muscle cells was determined by conversion to phosphorylation products by externally added DAG kinase from Escherichia coli in the presence of $\left[\gamma-{ }^{32} \mathrm{P}\right]$ ATP as described (26).
Palmitate oxidation. Fatty acid oxidation was essentially determined as previously described (27). Myoblasts were grown in a $25-\mathrm{cm}^{2}$ cell culture flask and differentiated to myotubes at $>80 \%$ confluence. Before starting the experiment, a 2-mm hole was made in the lid of each flask and two sheets of $24 \mathrm{~mm}$ Whatman filter (cat. no. 108340-24; VWR International) were encircled with a gauze bandage compass. The filter compass was then pressed into the inside of the culture flask lid. After 8 days differentiation, myotubes were serum starved overnight and treated for $180 \mathrm{~min}$ with $0.4 \mu \mathrm{Ci} 1-\left[{ }^{14} \mathrm{C}\right]$ palmitate in $2 \mathrm{ml}$ serum-free DMEM (containing $5 \mathrm{mmol} / \mathrm{lglucose}$ ) with or without 120 $\mathrm{nmol} / / \mathrm{insulin}$ at $37^{\circ} \mathrm{C}$. After treatment, $200 \mu \mathrm{l}$ Solvable reagent (benzethonium hydroxide; Packard) was added dropwise through the hole of the flask lid to soak the filter. Thereafter, $300 \mu \mathrm{l}$ of $70 \%$ perchloric acid was injected through the hole and filter. The lids were sealed with flexible film (Parafilm; Nordic EM Supplies, Espoo, Finland). Flasks were then laid down with slight agitation for $1 \mathrm{~h}$ at room temperature. Thereafter, the filter compass was removed to a scintillation tube with $10 \mathrm{ml}$ scintillation liquid and $200 \mu \mathrm{l}$ ice-cold methanol was added. The trapped $\left[{ }^{14} \mathrm{CO}_{2}\right]$ in the filter was then counted in a liquid scintillation counter. Protein content of each sample was determined by the BioRad method.

Intracellular accumulation of radioactive palmitate (palmitate uptake). As an indication of free fatty acid uptake, flasks from the palmitate oxidation experiment described above were washed five times with Trisbuffered saline plus Tween (TBST) and cells were lysed with $2 \mathrm{ml} 0.03 \%$ SDS for $2 \mathrm{~h}$ at room temperature with slight agitation. Lysates $(400 \mu \mathrm{l})$ were then transferred to $4 \mathrm{ml}$ scintillation fluid, and palmitate uptake, as determined by the accumulated $1-\left[{ }^{14} \mathrm{C}\right]$ in the lysate, was assessed by liquid scintillation counting. The total lipid accumulation was calculated by adding the amount oxidized to the amount accumulated.

Glucose oxidation. Cells were cultured in $25-\mathrm{cm}^{2}$ flasks. Myotubes were incubated for $60 \mathrm{~min}$ in $2 \mathrm{ml}$ serum-free DMEM containing $5 \mathrm{mmol} / \mathrm{l}$ glucose and $2 \mathrm{mCi} / \mathrm{ml} \mathrm{D}-\left[\mathrm{U}_{-}{ }^{14} \mathrm{C}\right]$ glucose in the absence or presence or insulin $(120$ $\mathrm{nmol} / \mathrm{l})$ at $37^{\circ} \mathrm{C}$ in $5 \% \mathrm{CO}_{2}-95 \% \mathrm{O}_{2}$. Trapping of $\left[{ }^{14} \mathrm{CO}_{2}\right]$ to determine whether the labeled glucose had been metabolized was performed as described above for palmitate oxidation. Protein content of each sample was determined by the BioRad method.

Glucose conversion into glycogen. Glycogen synthesis was determined by assessing the conversion of labeled glucose into glycogen, as previously described (24). Myotubes cultured in sixwell plates containing $5 \mathrm{mmol} / \mathrm{l}$ glucose DMEM supplemented with $\mathrm{D}_{-}\left[\mathrm{U}_{-}{ }^{14} \mathrm{C}\right]$ glucose $(1 \mu \mathrm{Ci} / \mathrm{ml}$; final specific activity, $0.18 \mu \mathrm{Ci} / \mu \mathrm{mol}$ ) were incubated in the absence or presence of insulin $(120 \mathrm{nmol} / \mathrm{l})$ for $90 \mathrm{~min}$ at $37^{\circ} \mathrm{C}$. Each experiment was performed on triplicate wells.

Lactate concentration. Myotubes were stimulated with or without insulin $(120 \mathrm{nmol} / \mathrm{l})$ in serum-free DMEM. Media $(100 \mu \mathrm{l})$ were collected in duplicates and lactate concentration was determined as previously described (27), using a lactate kit (A-108; Biochemical Research Service Center, University at Buffalo, Buffalo, NY).

Glucose transport and cell surface GLUT1/4 content. Myotubes were transfected with siRNA against a scrambled sequence or MCD as described above. Control or transfected myotubes were incubated in the absence or presence of insulin $(120 \mathrm{nmol} / \mathrm{l})$ for $1 \mathrm{~h}$. 2-deoxyglucose uptake was performed as previously described for primary human muscle cells $(23,28)$. Cell-surface GLUT1 and GLUT4 content was performed as previously described for primary human muscle cells (28). Myotubes were incubated as described for glucose transport, followed by incubation at $18^{\circ} \mathrm{C}$ for 5 min. Cells were then rinsed and incubated for 8 min with Krebs-Henseleit bicarbonate buffer supplemented with $5 \mathrm{mmol} / \mathrm{l}$ HEPES and $0.1 \%$ BSA, with $100 \mu \mathrm{mol} / \mathrm{l}$ Bio-LC-ATB-BGPA \{4,4'-O-[2-[2-[2-[2-[2-[6(biotinylamino)hexanoyl]amino] ethoxy] ethoxy] ethoxy]-4-(1-azi-2,2,2,rifluoro-ethyl)benzoyl] amino-1,3-propanediyl bis-D-glucose\} (a kind gift from Dr. Geoffrey Holman, University of Bath, U.K.). Dishes were subsequently ultraviolet irradiated for $3 \mathrm{~min}$. Cells were washed with PBS, solubilized, and scraped into $1 \mathrm{ml}$ PBS with $2 \%$ thesit $\left(\mathrm{C}_{12} \mathrm{E}_{9}\right)$ and protease inhibitors $(10 \mu \mathrm{g} / \mathrm{ml}$ aprotinin, $10 \mu \mathrm{g} / \mathrm{ml}$ antipain, $10 \mu \mathrm{g} / \mathrm{ml}$ leupetin, and $200 \mu \mathrm{mol} / \mathrm{l}$ phenylmethylsulfonyl fluoride). Solubilized cell extracts were then transferred to microtubes (Sarstedt, Nümbrecht, Germany) and rotated for $60 \mathrm{~min}$ at $4^{\circ} \mathrm{C}$. Cell lysates were centrifuged for $10 \mathrm{~min}$ at $20000 \mathrm{~g}$. The supernatant was collected, and protein concentration was determined. Equal amount of protein was mixed with $50 \mu$ l PBS-washed streptavidin agarose beads (50\% slurry; Pierce). The streptavidin-biotin complex was incubated overnight at $4^{\circ} \mathrm{C}$ with end-to-end rotation. Beads were washed three times with PBS-1\% thesit, three times with PBS- $0.1 \%$ thesit, and twice with PBS. An aliquot (30 $\mu$ l) Laemmeli buffer was lamp heated for $40 \mathrm{~min}$. Photolabeled glucose transporters were eluted from the beads by heating in $50 \mu \mathrm{l}$ Laemmeli buffer at $56^{\circ} \mathrm{C}$ for $20 \mathrm{~min}$. Samples were directly applied to SDS-PAGE and subjected to electrophoresis. Proteins 
were transferred and subjected to immunoblot analysis to determine cell-surface GLUT1 and GLUT4 as described (28).

Insulin signaling. Myoblasts were incubated for $20 \mathrm{~min}$ in the absence or presence of insulin (120 nmol/l) and then scraped into ice-cold homogenizing buffer $(20 \mathrm{mmol} / \mathrm{l}$ Tris $\mathrm{pH} 8.0,135 \mathrm{mmol} / \mathrm{l} \mathrm{NaCl}, 1 \mathrm{mmol} / \mathrm{l} \mathrm{MgCl}, 2.7 \mathrm{mmol} / \mathrm{l}$ $\mathrm{KCl}, 10 \mathrm{mmol} / \mathrm{l} \mathrm{Na} \mathrm{P}_{2} \mathrm{O}_{7}, 0.5 \mathrm{mmol} / \mathrm{l} \mathrm{Na}_{3} \mathrm{VO}_{4}, 10 \mathrm{mmol} / \mathrm{l} \mathrm{NaF}, 1 \mu \mathrm{mol} / \mathrm{l}$ microcystin, $1 \%$ Triton $\mathrm{X}-100,10 \% \mathrm{vol} / \mathrm{vol}$ glycerol, $0.2 \mathrm{mmol} / \mathrm{l}$ phenylmethylsulfonyl fluoride, $10 \mu \mathrm{g} / \mathrm{ml}$ leupeptin, and $10 \mu \mathrm{g} / \mathrm{ml}$ aprotinin). Cells were lysed by repeated pipetting, and lysates were agitated for $60 \mathrm{~min}$ at $4^{\circ} \mathrm{C}$ and subjected to centrifugation $\left(12,000 \mathrm{~g}\right.$ for $10 \mathrm{~min}$ at $\left.4^{\circ} \mathrm{C}\right)$. After protein determination, an aliquot of $300 \mu \mathrm{g}$ protein was immunoprecipitated overnight $\left(4^{\circ} \mathrm{C}\right)$ with anti-phosphotyrosine antibody coupled to protein A-sepharose (Sigma). Phosphatidylinositol (PI) 3-kinase activity was assessed directly on the protein A-sepharose beads as previously described (29). Reaction products were resolved by thin-layer chromatography and quantified using PhosphoImager Bio-Rad Laboratories (Richmond, CA).

Western blot analysis. Aliquots of cell lysate ( $20 \mu \mathrm{g}$ protein) or anti-IRS-1 immunodepleted samples were resuspended in Laemmli sample buffer. Proteins were then separated by SDS-PAGE, transferred to polyvinylidene difluoride membranes (Millipore, MA), blocked with $7.5 \%$ nonfat milk, washed with TBST (10 mmol/l Tris $\mathrm{HCl}, 100 \mathrm{mmol} / \mathrm{l} \mathrm{NaCl}$, and $0.02 \%$ Tween 20 ), and incubated with appropriate primary antibodies overnight at $4^{\circ} \mathrm{C}$. Membranes were washed with TBST and incubated with an appropriate secondary antibody. Proteins were visualized by enhanced chemiluminescence and quantified by densitometry. Phosphospecific antibodies against Akt $\left(\mathrm{Ser}^{473}\right)$, GSK $\alpha / \beta\left(\operatorname{Ser}^{21 / 9}\right)$, and AMPK $\left(\mathrm{Thr}^{172}\right.$ ) were from Cell Signaling. The IRS-1 polyclonal antibody was from Upstate Biotechnology. The rabbit polyclonal antibody to phosphotyrosine was from BD Transduction Laboratories.

Statistics. Results are presented as mean \pm SE. Differences between groups were determined by two-way ANOVA or paired Student's $t$ test. When ANOVA was applied, Fisher's least-significant difference post hoc analysis was used to identify significant differences.

\section{RESULTS AND DISCUSSION}

MCD silencing in human myotubes. The major pathway for malonyl-CoA degradation is via MCD, which decarboxylates malonyl-CoA to acetyl-CoA. MCD inhibition has been proposed as a novel strategy to treat ischemic heart disease and obesity, namely by allowing full oxidation of glucose rather than elevated lactic acid and proton production leading to diminished cardiac efficiency (30). The potential effects of MCD inhibition on peripheral tissues such as skeletal muscle, a major tissue involved in the regulation of whole body glucose homeostasis, are unknown. Based on work in cardiac muscle, MCD inhibition would be predicted to shift bioenergetics in skeletal muscle from lipid to glucose oxidation. To test this hypothesis, we used RNA interference to silence MCD gene expression in differentiated myotubes. We have previously utilized this approach to silence genes in the insulinsignaling cascade in primary human skeletal muscle (24,31). MCD gene expression was reduced $75 \%(P<$ $0.001)$ compared with that in cells that were either untransfected or transfected with scrambled siRNA (Fig. 1). Cell survival was unaltered in MCD-depleted myotubes.

MCD depletion alters palmitate oxidation and uptake. During and after a cardiac ischemic event, circulating free fatty acid levels are elevated and lipid oxidation serves as a major source of oxidative metabolism. Genetic or pharmacological inhibition of MCD in cardiac muscle increases malonyl-CoA, thereby inhibiting lipid oxidation and increasing glucose oxidation (30). MCD silencing increased malonyl-CoA levels twofold (Fig. 2A), whereas CoASH, acetyl-CoA, DAG, and ceramide levels were unaltered (Fig. 2B-E). An increase in malonyl-CoA inhibits CPT-1, the rate-limiting enzyme in fatty acid import into mitochondria for oxidation (7). Malonyl-CoA can bind to CPT-1 via its regulatory domain and therefore inactivate the enzyme (32); thus, we determined whether MCD gene silencing alters lipid metabolism in human muscle. In

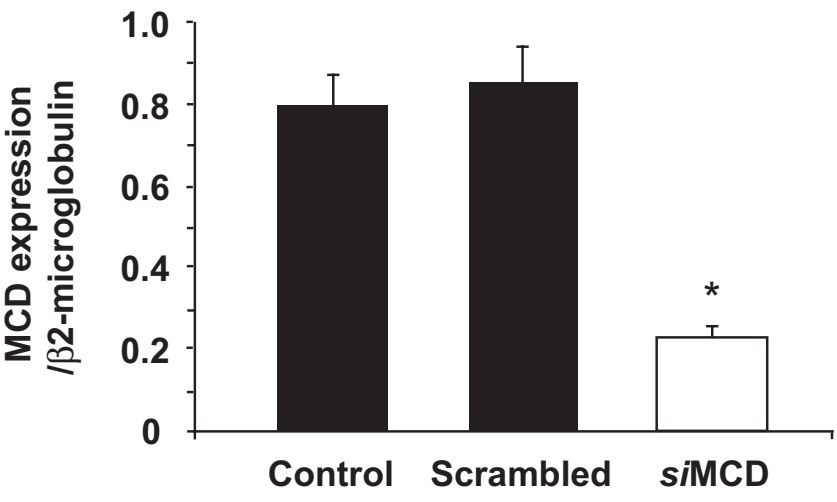

FIG. 1. Effect of MCD siRNA on mRNA expression. mRNA expression of MCD in human skeletal muscle myotubes. Myotubes were transfected with siRNA against MCD (siMCD) or a scrambled sequence. Untransfected myotubes were used as control. MCD mRNA is reported relative to $\beta 2$-microglobulin mRNA expression. Results are expressed as means \pm SE. $* P<0.05$ vs. scrambled siRNA.

control cells and cells transfected with scrambled siRNA, insulin suppressed palmitate oxidation 2.8-fold (Fig. 3A) and increased the accumulation of intracellular palmitate 1.5-fold (Fig. 3B). RNA interference-mediated depletion of MCD suppressed basal palmitate oxidation (Fig. $3 A$ ). This response was similar to the effect of insulin to suppress palmitate oxidation in control cells. Suppression of MCD further reduced palmitate oxidation under insulin-stimulated conditions. MCD silencing also decreased (40\%) the basal rate of palmitate uptake and markedly impaired (49\%) the insulin-stimulated response (Fig. 3B). We also assessed the effects of MCD depletion on mRNA expression of fatty acid transport protein member (FATP)-1 and pyruvate dehydrogenase kinase (PDK)4 (Table 1). FATP-1 facilitates the transport of fatty acids across the cell membrane, and PDK4 phosphorylates and inactivates the pyruvate dehydrogenase complex, which controls the entry of carbohydrates into the tricarboxylic cycle. MCD silencing increased mRNA expression of FATP-1 and was without effect on expression of PDK4. We were unable to confirm these results at the level of protein expression as a result of insufficient availability of sample. Collectively, these results provide evidence that MCD plays a key role in regulating lipid oxidation. Our results are compatible with pharmacological studies that report chemical inhibition of MCD decreases lipid oxidation in mouse heart due to an increase in the malonyl-CoA level (33). These results are recapitulated in $\mathrm{MCD}^{-1-}$ mice (17), as evident by reduced rates of fat catabolism and protection from dietaryinduced insulin resistance despite elevated levels of skeletal muscle long-chain acyl-CoAs and a tendency for increased triacylglycerol levels.

MCD depletion increases glucose metabolism. A reciprocal relationship between lipid and glucose oxidation has long been appreciated (34). Indeed chronic inhibition of MCD using whole-body knockout mice (20) provides protection against the development of glucose intolerance and hyperglycemia associated with high-fat diet (17). Interestingly, the respiratory exchange ratio was higher in $\mathrm{MCD}^{-1-}$ mice fed a high-fat diet compared with that in wild-type littermates, reflecting increased rates of glucose rather than lipid oxidation at the whole-body levels. These findings suggest that skeletal muscle glucose uptake and catabolic metabolism may be enhanced as a consequence of targeted depletion of MCD. Thus, we determined 


\section{A \\ B \\ C}

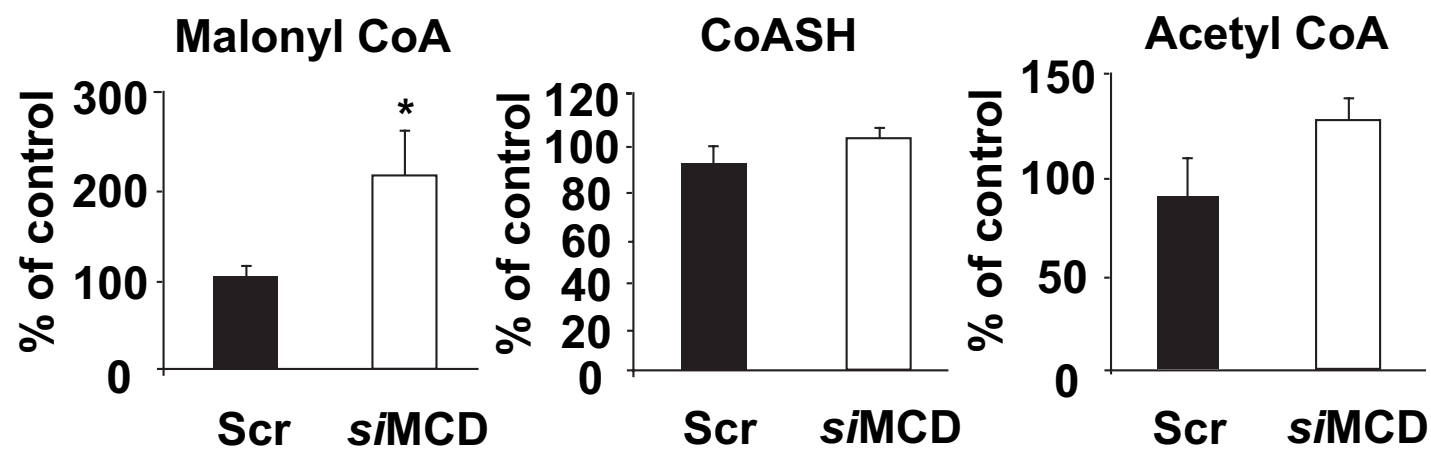

D

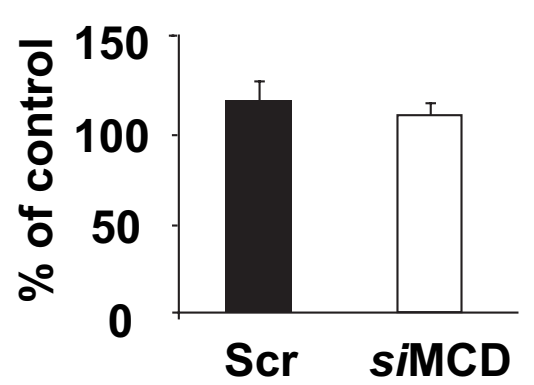

E

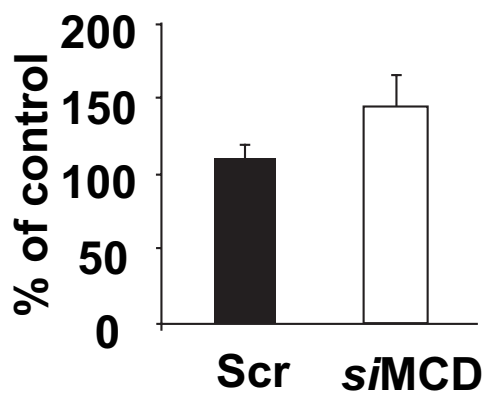

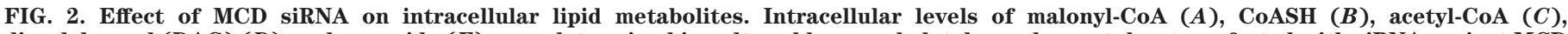

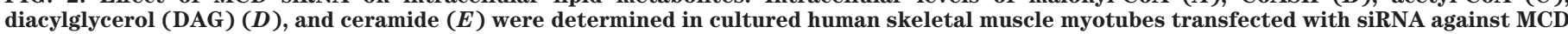
( siMCD) or a scrambled sequence (Scr). Results are expressed as means \pm SE/percentages of control. $* P<0.05$ vs. scrambled siRNA.

whether MCD led to a reciprocal relationship between lipid and glucose oxidation in primary human muscle cells. Four days after transfection, glucose oxidation was assessed under basal and insulin-stimulated conditions. In control or myotubes transfected with scrambled siRNA, insulin increased glucose oxidation 1.7-fold (Fig. 4A). Gene silencing of MCD increased basal and insulinmediated glucose oxidation 1.4- and 2.6-fold, respectively.

The consequences of MCD silencing on glycogen synthesis was next determined. In control or cells transfected with scrambled siRNA, insulin increased glycogen synthesis 1.8-fold (Fig. 4B). In myotubes in which MCD was depleted, basal glycogen synthesis was increased by 1.3fold compared with that in untransfected cells. Insulinstimulated glucose incorporation to glycogen was unaltered by MCD depletion. Glucose can be degraded through anaerobic metabolism to produce lactate. The increase in glucose metabolism can promote lactate production by the conversion of pyruvate by lactate dehydrogenase. Skeletal muscle is considered the major site of lactate production (35). In control cells, insulin increased lactate production 1.6-fold (Fig. 4C). siRNA-mediated MCD silencing decreased basal and insulin-stimulated lactate production. An increase in fasting plasma lactate levels has been proposed as an independent risk factor for development of type 2 diabetes $(36,37)$. MCD inhibition decreased the rate of glycolysis, as estimated by a reduction in lactate release, and augmented the rate of glycogen synthesis. Alternatively, the reduced lactate production in MCD-depleted myotubes may occur in response to the increase in glucose oxidation rather than a decrease in glycolysis.

MCD depletion increases glucose uptake but not insulin signaling. To provide insight into the mechanism by which suppression of MCD expression and fatty acid oxidation lead to enhanced glucose oxidation, glucose transport and cell surface glucose transporters were determined. Four days after transfection, basal and insulinstimulated glucose uptake was assessed (Fig. 5A). Insulin increased glucose uptake 1.7-fold in controls and in cells transfected with scrambled siRNA. RNA interferencemediated depletion of MCD increased basal glucose transport compared with that in control myotubes. Insulinstimulated glucose transport was also increased in MCDdepleted myotubes; however, this effect appeared to be a consequence of the increased basal glucose uptake, since the fold-insulin stimulation was similar to the effect noted in control cells. Glucose transport across the cell membrane is mediated by a family of structurally related transport proteins that can be translocated from intracellular sites to the plasma membrane. Cell-surface GLUT1 content was unaltered between basal and insulin-stimulated conditions (Fig. 5B), consistent with the notion that GLUT1 primarily mediates basal glucose transport (38). Moreover, depletion of MCD did not alter cell-surface GLUT1 levels. Insulin stimulation of glucose transport activity correlates closely with the appearance of GLUT4 on the cell surface (38). Here, we report that insulin increased cell-surface GLUT4 levels in primary human myotubes 2.5-fold (Fig. 5C). MCD silencing increased 


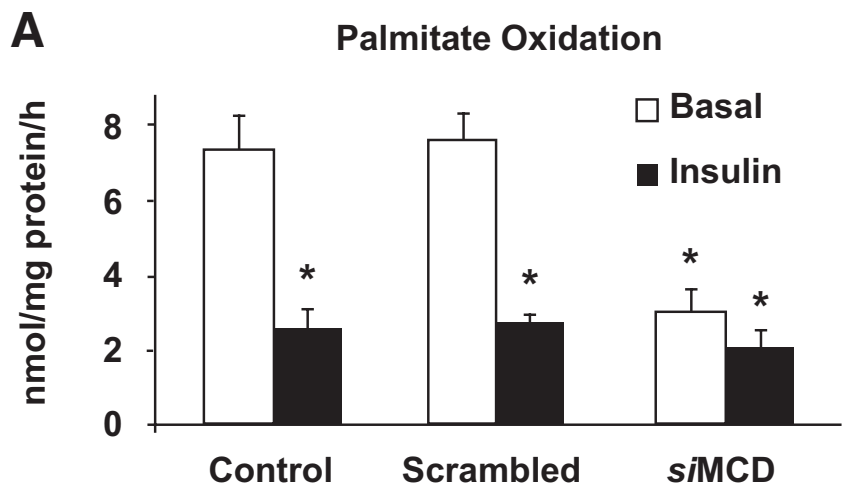

B

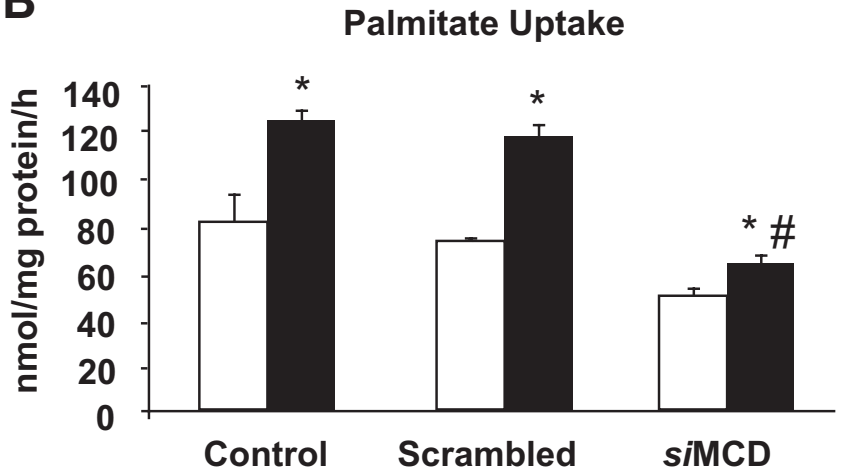

FIG. 3. Effect of MCD siRNA on palmitate oxidation and uptake. Palmitate oxidation $(A)$ and uptake $(B)$ under basal or insulin-stimulated conditions in primary human skeletal myotubes. Palmitate oxidation and uptake are reported as nanomoles per milligrams protein per hour. Results are expressed as means \pm SE. $* P<0.05$ vs. untransfected cells at basal; \#P $<0.05$ vs. untransfected cells after insulin stimulation.

cell-surface GLUT4 content under basal and insulin-stimulated conditions, and this response was comparable with the observed changes in glucose transport and oxidation. Thus, MCD inhibition promotes glucose transport by increasing cell-surface GLUT4 levels and glucose metabolism primarily via oxidative rather than nonoxidative pathways.

Insulin regulates glucose and lipid metabolism by signal transduction pathways involving protein phosphorylation cascades (39). To determine whether the changes in lipid and glucose metabolism that we observed were associated with alterations in insulin signaling, we determined the effect of MCD inhibition on insulin signaling (Fig. 6).

TABLE 1

mRNA content of select genes in human myotubes determined using RT-PCR

\begin{tabular}{lcc}
\hline Gene & Scrambled & siMCD \\
\hline FATP- 1 & $0.98 \pm 0.25$ & $1.22 \pm 0.29^{*}$ \\
PDK-4 & $0.99 \pm 0.16$ & $0.89 \pm 0.24$ \\
AMPK- $\alpha 1$ & $1.02 \pm 0.10$ & $1.00 \pm 0.09$ \\
AMPK- $\alpha 2$ & $0.96 \pm 0.24$ & $0.74 \pm 0.13$ \\
ACC- $\alpha$ & $0.98 \pm 0.24$ & $0.87 \pm 0.18$ \\
ACC- $\beta$ & $0.98 \pm 0.32$ & $1.12 \pm 0.27$
\end{tabular}

Data are means \pm SE. Cells were transfected with siRNA against a scrambled sequence or MCD (siMCD). Results are reported as percentage of control (nontransfected myotubes) and normalized to glyceraldehyde-3-phosphate dehydrogenase. Paired Student's $t$ test comparisons were made between groups (scrambled vs. siMCD). *Significantly different from scrambled $(P<0.05)$.

\section{A Glucose Oxidation}

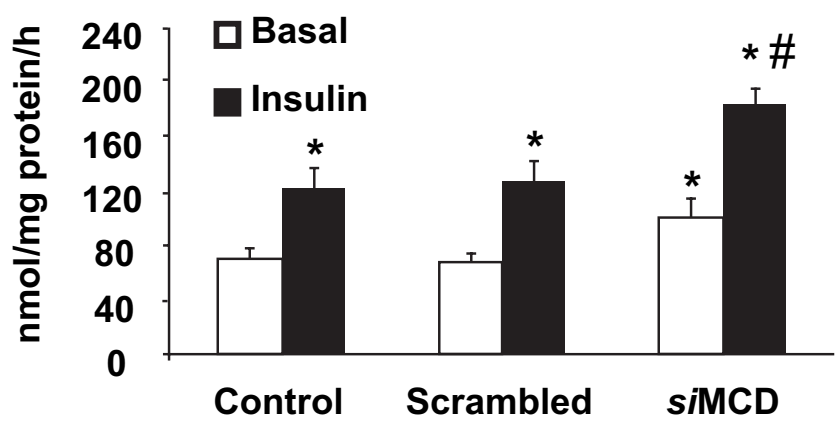

B

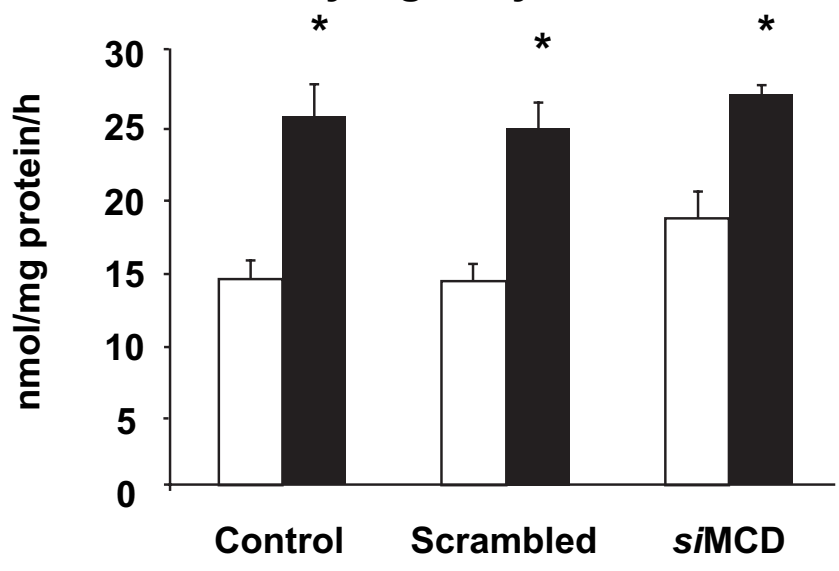

C Lactate Production

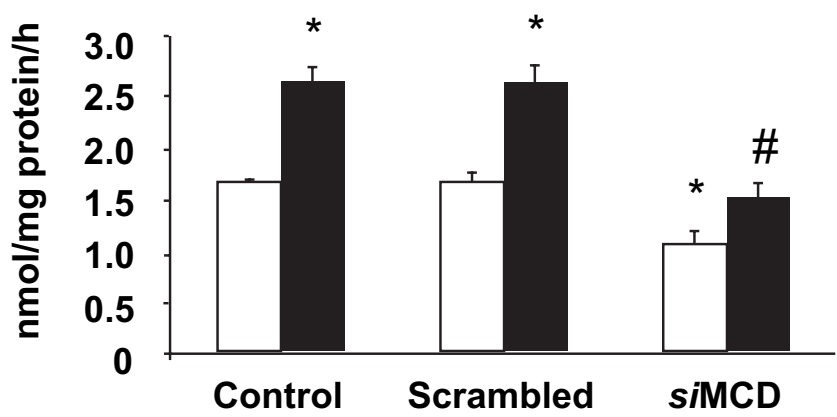

FIG. 4. Effect of MCD siRNA on glucose metabolism. Glucose metabolism and lactate release were determined in primary human skeletal myotubes under basal or insulin-stimulated conditions. Glucose oxidation $(A)$, glycogen synthesis $(B)$, and lactate production $(C)$ are reported as nanomoles per milligrams protein per hour. Results are expressed as means \pm SE. $* P<0.05$ vs. untransfected cells at basal; $\# P<0.05$ vs. untransfected cells after insulin stimulation.

Insulin receptor tyrosine phosphorylation was increased 1.8-fold by insulin (Fig. $6 A$ ), and this response was unaltered by depletion of MCD. Similarly, IRS-1-associated PI 3-kinase activity (Fig. $6 B$ ) and Akt Ser ${ }^{473}$ phosphorylation (Fig. 6C) were markedly increased in response to insulin but not MCD knockdown. The increase in glucose transport and metabolism observed in MCD-depleted cells in the absence of changes in insulin signaling may be explained by the spare receptor and signaling capacity leading to additional GLUT4 translocation. Indeed, the concentration of insulin required to maximally activate glucose transport corresponds to $<15 \%$ of maximal receptor kinase activity (40) and, therefore, changes in glucose 
A

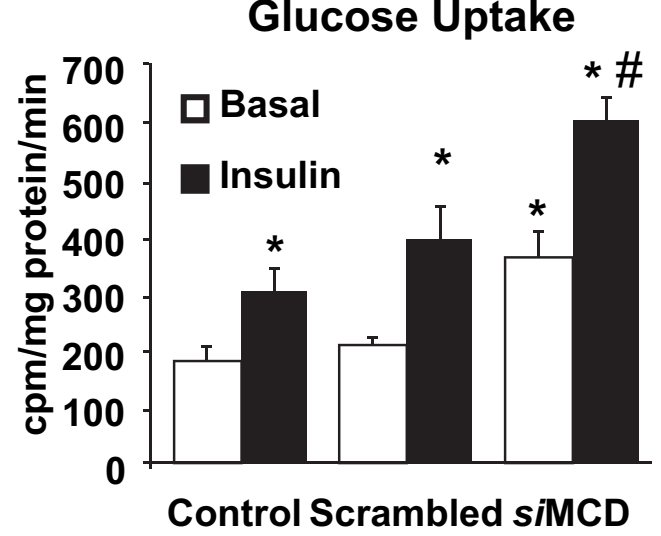

B
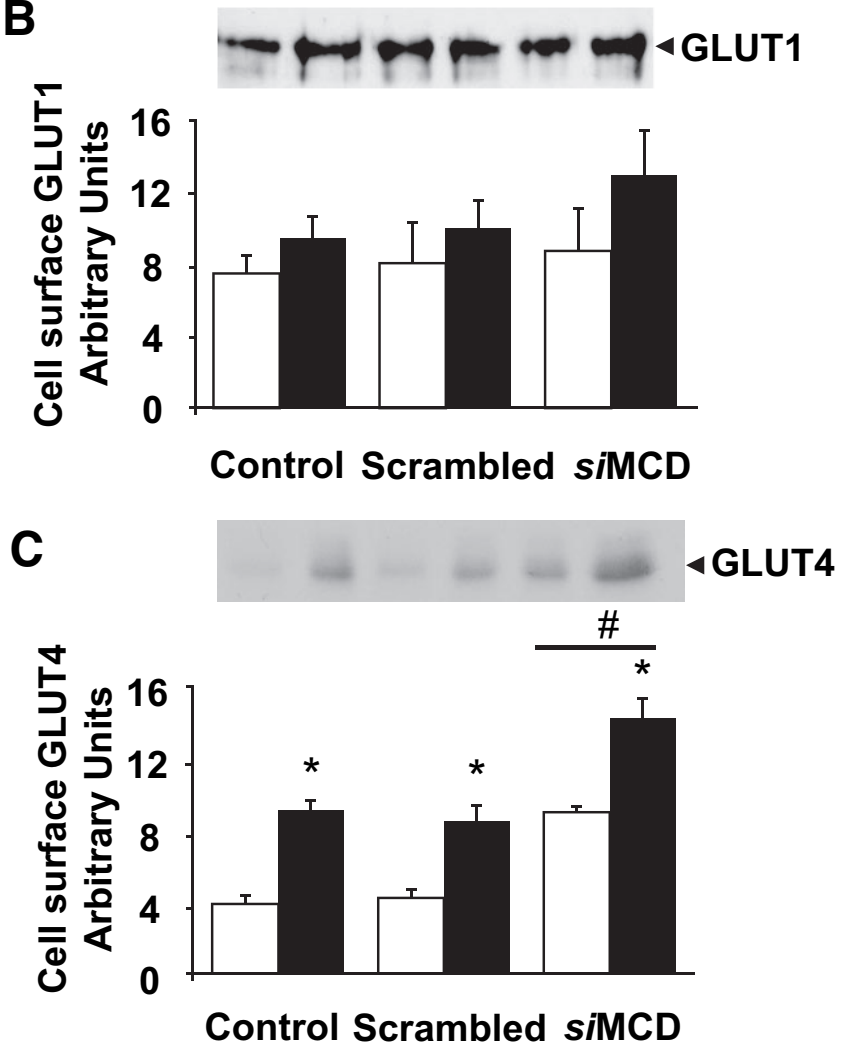

FIG. 5. Effect of MCD siRNA on glucose transport and cell-surface glucose transporters. Glucose uptake and cell-surface GLUT1 and GLUT4 were determined in primary human skeletal myotubes under basal or insulin-stimulated conditions. Glucose uptake $(A)$ is reported as cpm per milligrams protein per min. Cell-surface GLUT1 $(B)$ and GLUT4 $(C)$ are reported as arbitrary units. Representative immunoblots for cell-surface GLUT1 and GLUT4 are shown about each respective graph. Results are expressed as means \pm SE. $* P<0.05$ vs. untransfected cells at basal; \#P $<0.05$ vs. untransfected cells after insulin stimulation.

uptake can occur in the absence of an augmentation in insulin signaling. Nevertheless, we cannot exclude the possibility that MCD depletion leads to enhanced insulin sensitivity in steps beyond Akt. To address this possibility, we also tested whether MCD depletion altered phosphorylation of GSK3. Akt inactivates GSK3, leading to the dephosphorylation and activation of glycogen synthase and, hence, to an acceleration of glycogen synthesis (41). In skeletal muscle, insulin stimulates dephosphorylation of glycogen synthase by inactivating GSK3 $\alpha$ and GSK3 $\beta$ via phosphorylation of serine residues (42). Insulin in-
A
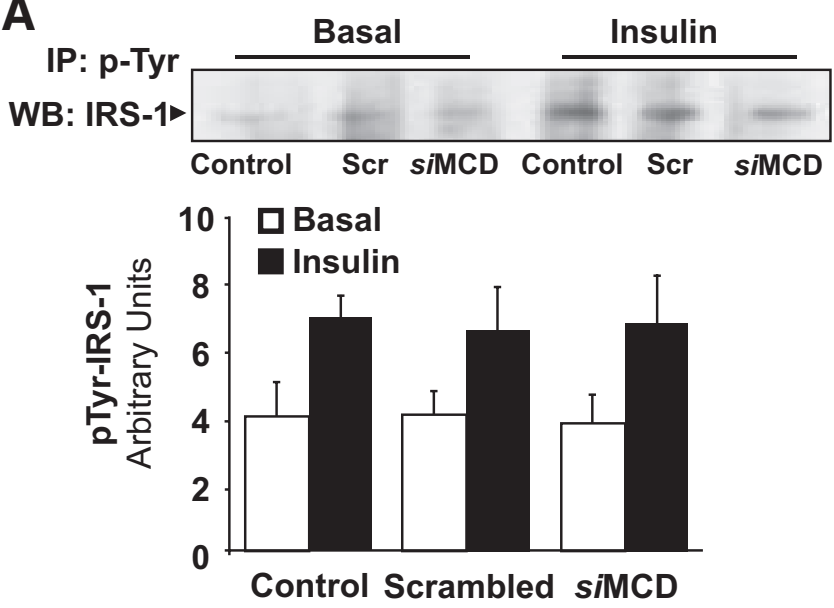

B
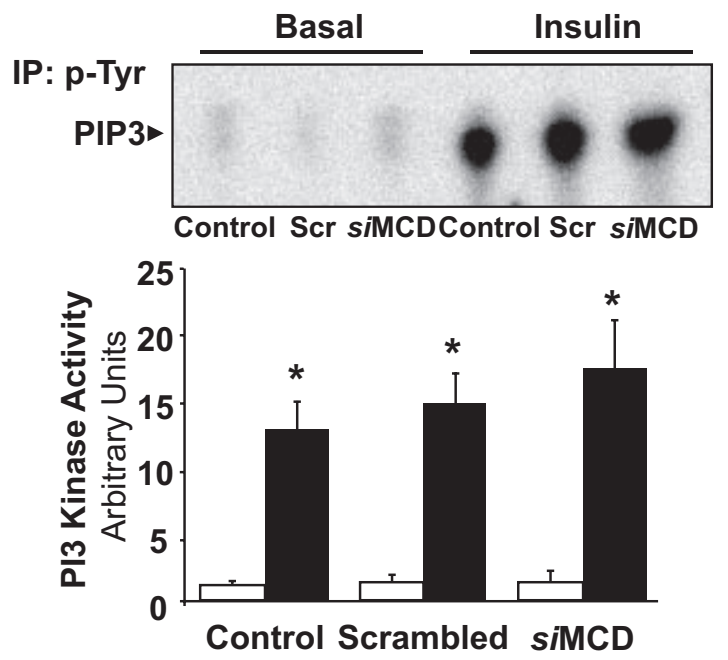

C

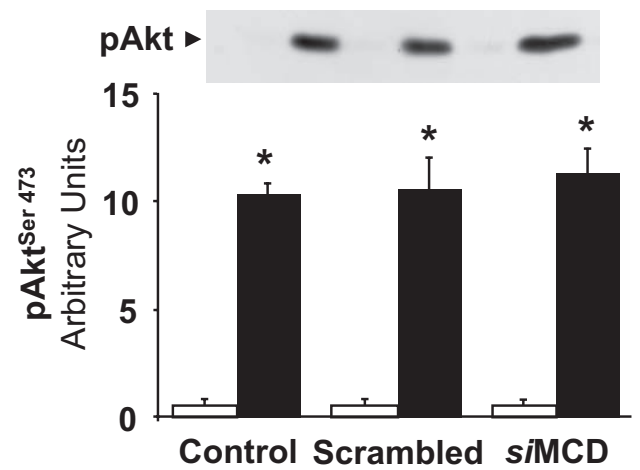

FIG. 6. Effect of MCD siRNA on insulin signaling. IRS-1 tyrosine phosphorylation $(A)$, tyrosine-associated PI 3-kinase activity $(B)$, and Akt Ser ${ }^{473}$ phosphorylation $(C)$ were determined under basal or insulin-stimulated conditions in primary human skeletal myotubes studied under control conditions or after transfection with siRNA against a scrambled sequence or MCD (siMCD). Representative immunoblots are shown for IRS-1 tyrosine and Akt phosphorylation, respectively. Representative phospho-image is shown for PI-3 kinase activity. Results are expressed as means \pm SE arbitrary units. $* P<0.05$ vs. untransfected cells at basal.

creased GSK3 $\alpha$ and GSK3 $\beta$ serine phosphorylation twofold (Fig. 7), and this response was unaltered by MCD depletion. Collectively, our data provide evidence that MCD leads to changes in lipid and glucose oxidation, independent of alterations in insulin signaling. 

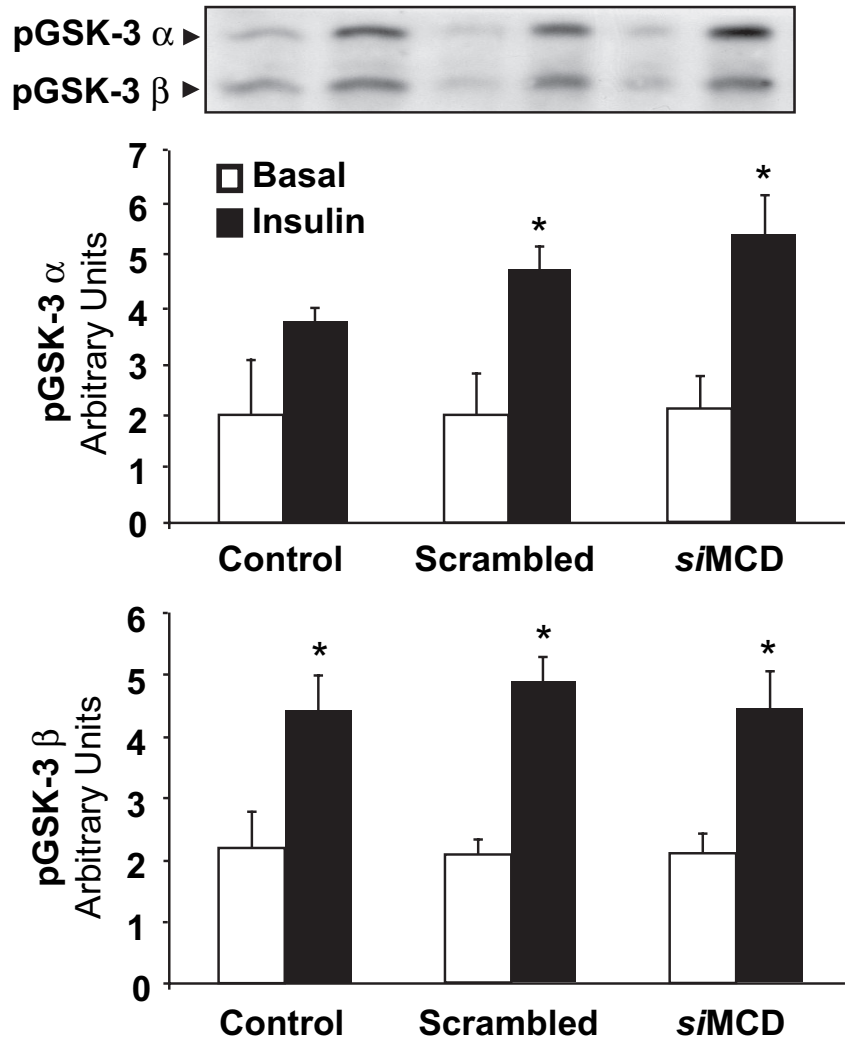

FIG. 7. Effect of MCD siRNA on GSK3 phosphorylation. Serine phosphorylation of GSK3 $\alpha$ and GSK3 $\beta$ was determined under basal or insulin-stimulated conditions in primary human skeletal myotubes studied under control conditions or after transfection with siRNA against a scrambled sequence or MCD (siMCD). Representative immunoblots are shown. Results are expressed as means \pm SE. $* P<0.05$ vs. untransfected cells at basal.

MCD depletion does not affect AMPK phosphorylation. MCD regulates malonyl-CoA levels by signal transduction via AMPK through phosphorylation and inhibition of ACC, the rate-limiting enzyme in malonyl-CoA synthesis $(6,12)$. Under physiological conditions, fuel availability and energy expenditure may influence malonyl-CoA levels (13) by reciprocal regulation between AMPK and MCD (14). Since we perturbed the malonyl-CoA pathway downstream of AMPK, we could not exclude the possibility that an alteration in MCD expression may feedback on AMPK activity. To address this issue, we assessed AMPK phosphorylation (Fig. 8). Myotubes were incubated in the absence or presence of insulin, and AMPK Thr ${ }^{172}$ was determined. AMPK phosphorylation was similar between myotubes incubated under control conditions in the absence or presence of insulin. In myotubes transfected with siRNA against a scrambled sequence, AMPK phosphorylation under insulin-stimulated conditions was reduced. This finding was inconsistent with all other parameters studied. Treatment of myotubes with siRNA against MCD was without effect on AMPK phosphorylation. Thus, depletion of MCD modifies malonyl-CoA levels downstream or independently of AMPK. In addition, mRNA of AMPK- $\alpha 1$ and $-\alpha 2$ subunits and ACC $\alpha$ and ACC $\beta$ were unaltered between myotubes transfected with siRNA against a scrambled sequence or MCD versus control cells (Table 1).

Malonyl-CoA has been identified as a critical mediator in the hypothalamic sensing of energy balance $(11,18)$. Inhibition of fatty acid synthase directly in the hypothalamus increases the level of malonyl-CoA and suppresses food
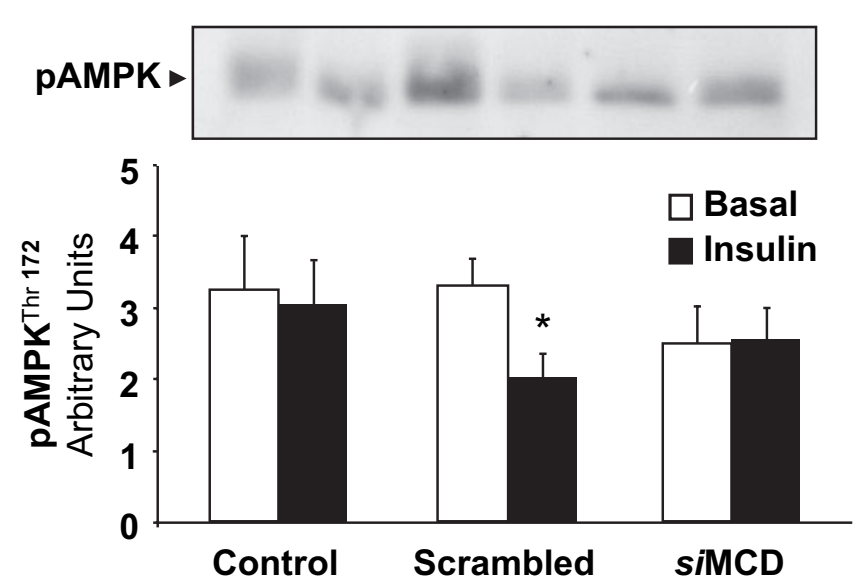

FIG. 8. Effect of MCD siRNA on AMPK phosphorylation. AMPK Thr ${ }^{172}$ phosphorylation was determined under basal or insulin-stimulated conditions in primary human skeletal myotubes studied under control conditions or after transfection with siRNA against a scrambled sequence or MCD (siMCD). Representative immunoblots are shown. Results are expressed as means \pm SE. $* P<0.05$ vs. untransfected cells at basal.

intake, increases skeletal muscle fatty acid oxidation, and causes weight loss (11). Conversely, hypothalamic overexpression of MCD (21), inhibition of ACC (11), or activation of AMPK (43) to decrease the level of malonyl-CoA stimulates food intake. While the long-term effect of skeletal muscle MCD inhibition is unknown, chronic elevations in the local concentration of malonyl-CoA due to glucose infusion (44) or diabetes (13) are associated with peripheral and hepatic insulin resistance, due in part to an increase in diacylglycerol content and feedback inhibition on insulin-signaling cascades (45). Conversely, wholebody deletion of MCD is associated with a shift from incomplete $\beta$-oxidation of lipids to glucose oxidation and in high-fat fed mice, particularly during the dark/active cycle when systemic substrate use is predominantly influenced by the catabolic activity of skeletal muscle (17). The direct effects of whole-body MCD inhibition on wholebody glucose homeostasis in humans are difficult to predict, particularly in light of the potent hypothalamic effects of malonyl-CoA to inhibit food intake.

In conclusion, we provide evidence that siRNAmediated gene silencing directly validates MCD as a key modulator of skeletal muscle bioenergetics through coordinated changes in substrate utilization (Fig. 9). Inhibition of MCD in skeletal muscle shifts oxidation metabolic substrates from lipids to glucose.

\section{ACKNOWLEDGMENTS}

We are grateful to Professor Geoffrey D. Holman (University of Bath, U.K.) for generously providing reagents to assess cell-surface glucose transporters.

This work has been funded with support obtained from the Swedish Research Council, the Swedish Diabetes Association, Swedish Center for Sports Research, the Foundation for Scientific Studies of Diabetology, the Strategic Research Foundation (INGVAR II), and the Commission of the European Communities (Contract No. LSHMCT-2004-005272 EXGENESIS, Contract No. LSHM-CT-2004512013 EUGENEHEART, and Contract No. LSHM-CT-2004512013 EUGENE2). 


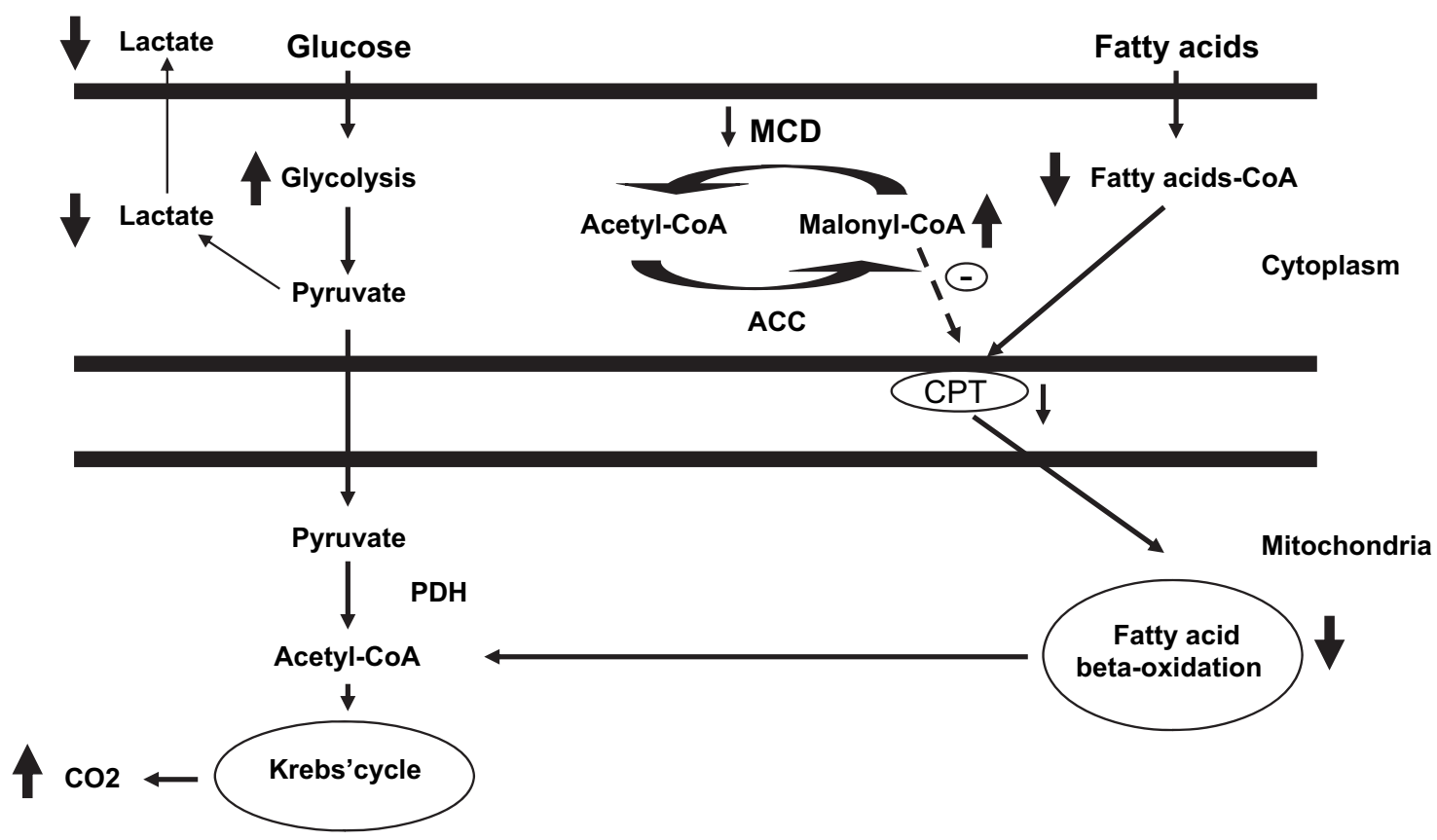

FIG. 9. Signaling pathways involving ACC and MCD regulate lipid and glucose metabolism. Malonyl-CoA is produced by ACC and catabolized by MCD. Malonyl-CoA is the first intermediate regulator in the synthesis of LCFA. Malonyl-CoA allosterically binds to CPT-1, thereby inhibiting the enzyme and the transfer of long-chain fatty acids into the mitochondria. siRNA-mediated gene silencing of MCD in skeletal muscle shifts oxidation and uptake of metabolic substrates from lipids to glucose.

\section{REFERENCES}

1. Virkamaki A, Korsheninnikova E, Seppala-Lindroos A, Vehkavaara S, Goto $\mathrm{T}$, Halavaara J, Hakkinen AM, Yki-Jarvinen H: Intramyocellular lipid is associated with resistance to in vivo insulin actions on glucose uptake, antilipolysis, and early insulin signaling pathways in human skeletal muscle. Diabetes 50:2337-2343, 2001

2. Miranda PJ, DeFronzo RA, Califf RM, Guyton JR: Metabolic syndrome: definition, pathophysiology, and mechanisms. Am Heart J 149:33-45, 2005

3. Kelley DE: Skeletal muscle fat oxidation: timing and flexibility are everything. J Clin Invest 115:1699-1702, 2005

4. Pan DA, Lillioja S, Kriketos AD, Milner MR, Baur LA, Bogardus C, Jenkins $\mathrm{AB}$, Storlien LH: Skeletal muscle triglyceride levels are inversely related to insulin action. Diabetes 46:983-988, 1997

5. Petersen KF, Shulman GI: Etiology of insulin resistance. Am J Med 119:S10-S16, 2006

6. Ruderman N, Prentki M: AMP kinase and malonyl-CoA: targets for therapy of the metabolic syndrome. Nat Rev Drug Discov 3:340-351, 2004

7. McGarry JD, Mills SE, Long CS, Foster DW: Observations on the affinity for carnitine, and malonyl-CoA sensitivity, of carnitine palmitoyltransferase I in animal and human tissues: demonstration of the presence of malonylCoA in non-hepatic tissues of the rat. Biochem $J$ 214:21-28, 1983

8. Rasmussen BB, Wolfe RR: Regulation of fatty acid oxidation in skeletal muscle. Annu Rev Nutr 19:463-484, 1999

9. Ruderman NB, Saha AK, Vavvas D, Witters LA: Malonyl-CoA, fuel sensing, and insulin resistance. Am J Physiol 276:E1-E18, 1999

10. Long YC, Zierath JR: AMP-activated protein kinase signaling in metabolic regulation. J Clin Invest 116:1776-1783, 2006

11. Abu-Elheiga L, Matzuk MM, Abo-Hashema KA, Wakil SJ: Continuous fatty acid oxidation and reduced fat storage in mice lacking acetyl-CoA carboxylase 2. Science 291:2613-2616, 2001

12. Alam N, Saggerson ED: Malonyl-CoA and the regulation of fatty acid oxidation in soleus muscle. Biochem $J$ 334:233-241, 1998

13. Saha AK, Kurowski TG, Colca JR, Ruderman NB: Lipid abnormalities in tissues of the KKAy mouse: effects of pioglitazone on malonyl-CoA and diacylglycerol. Am J Physiol 267:E95-E101, 1994

14. Saha AK, Schwarsin AJ, Roduit R, Masse F, Kaushik V, Tornheim K, Prentki M, Ruderman NB: Activation of malonyl-CoA decarboxylase in rat skeletal muscle by contraction and the AMP-activated protein kinase activator 5-aminoimidazole-4-carboxamide-1-beta-D-ribofuranoside. J Biol Chem 275:24279-24283, 2000

15. Assifi MM, Suchankova G, Constant S, Prentki M, Saha AK, Ruderman NB: AMP-activated protein kinase and coordination of hepatic fatty acid metabolism of starved/carbohydrate-refed rats. Am J Physiol Endocrinol Metab 289:E794-E800, 2005
16. Roepstorff C, Halberg N, Hillig T, Saha AK, Ruderman NB, Wojtaszewski JF, Richter EA, Kiens B: Malonyl-CoA and carnitine in regulation of fat oxidation in human skeletal muscle during exercise. Am $J$ Physiol Endocrinol Metab 288:E133-E142, 2005

17. Koves TR, Ussher JR, Noland RC, Slentz D, Mosedale M, Ilkayeva O, Bain J, Stevens R, Dyck JR, Newgard CB, Lopaschuk GD, Muoio DM: Mitochondrial overload and incomplete fatty acid oxidation contribute to skeletal muscle insulin resistance. Cell Metab 7:45-56, 2008

18. Lane MD, Hu Z, Cha SH, Dai Y, Wolfgang M, Sidhaye A: Role of malonyl-CoA in the hypothalamic control of food intake and energy expenditure. Biochem Soc Trans 33:1063-1067, 2005

19. Saha AK, Ruderman NB: Malonyl-CoA and AMP-activated protein kinase: an expanding partnership. Mol Cell Biochem 253:65-70, 2003

20. Dyck JR, Hopkins TA, Bonnet S, Michelakis ED, Young ME, Watanabe M, Kawase Y, Jishage K, Lopaschuk GD: Absence of malonyl coenzyme A decarboxylase in mice increases cardiac glucose oxidation and protects the heart from ischemic injury. Circulation 114:1721-1728, 2006

21. He W, Lam TK, Obici S, Rossetti L: Molecular disruption of hypothalamic nutrient sensing induces obesity. Nat Neurosci 9:227-233, 2006

22. Al-Khalili L, Kramer D, Wretenberg P, Krook A: Human skeletal muscle cell differentiation is associated with changes in myogenic markers and enhanced insulin-mediated MAPK and PKB phosphorylation. Acta Physiol Scand 180:395-403, 2004

23. Bouzakri K, Roques M, Gual P, Espinosa S, Guebre-Egziabher F, Riou JP, Laville M, Le Marchand-Brustel Y, Tanti JF, Vidal H: Reduced activation of phosphatidylinositol-3 kinase and increased serine 636 phosphorylation of insulin receptor substrate-1 in primary culture of skeletal muscle cells from patients with type 2 diabetes. Diabetes 52:1319-1325, 2003

24. Bouzakri K, Zachrisson A, Al-Khalili L, Zhang BB, Koistinen HA, Krook A, Zierath JR: siRNA-based gene silencing reveals specialized roles of IRS-1/ Akt2 and IRS-2/Akt1 in glucose and lipid metabolism in human skeletal muscle. Cell Metab 4:89-96, 2006

25. Minkler PE, Kerner J, Kasumov T, Parland W, Hoppel CL: Quantification of malonyl-coenzyme A in tissue specimens by high-performance liquid chromatography/mass spectrometry. Anal Biochem 352:24-32, 2006

26. Preiss J, Loomis CR, Bishop WR, Stein R, Niedel JE, Bell RM: Quantitative measurement of sn-1,2-diacylglycerols present in platelets, hepatocytes, and ras- and sis-transformed normal rat kidney cells. $J$ Biol Chem 261:8597-8600, 1986

27. Al-Khalili L, Bouzakri K, Glund S, Lonnqvist F, Koistinen HA, Krook A: Signaling specificity of interleukin- 6 action on glucose and lipid metabolism in skeletal muscle. Mol Endocrinol 20:3364-3375, 2006

28. Al-Khalili L, Cartee GD, Krook A: RNA interference-mediated reduction in 
GLUT1 inhibits serum-induced glucose transport in primary human skeletal muscle cells. Biochem Biophys Res Commun 307:127-132, 2003

29. Krook A, Moller DE, Dib K, O'Rahilly S: Two naturally occurring mutant insulin receptors phosphorylate insulin receptor substrate-1 (IRS-1) but fail to mediate the biological effects of insulin: evidence that IRS-1 phosphorylation is not sufficient for normal insulin action. $J$ Biol Chem 271:7134-7140, 1996

30. Lopaschuk GD, Stanley WC: Malonyl-CoA decarboxylase inhibition as a novel approach to treat ischemic heart disease. Cardiovasc Drugs Ther 20:433-439, 2006

31. Bouzakri K, Zierath JR: MAP4K4 gene silencing in human skeletal muscle prevents TNF-alpha -induced insulin resistance. J Biol Chem 282:77837789,2007

32. Kolodziej MP, Zammit VA: Sensitivity of inhibition of rat liver mitochondrial outer-membrane carnitine palmitoyltransferase by malonyl-CoA to chemical- and temperature-induced changes in membrane fluidity. Biochem $J$ 272:421-425, 1990

33. Cheng JF, Huang Y, Penuliar R, Nishimoto M, Liu L, Arrhenius T, Yang G, O'Leary E, Barbosa M, Barr R, Dyck JR, Lopaschuk GD, Nadzan AM: Discovery of potent and orally available malonyl-CoA decarboxylase inhibitors as cardioprotective agents. J Med Chem 49:4055-4058, 2006

34. Randle PJ, Garland PB, Hales CN, Newsholme EA: The glucose fatty-acid cycle: its role in insulin sensitivity and the metabolic disturbances of diabetes mellitus. Lancet 1:785-789, 1963

35. Stanley WC, Gertz EW, Wisneski JA, Neese RA, Morris DL, Brooks GA: Lactate extraction during net lactate release in legs of humans during exercise. J Appl Physiol 60:1116-1120, 1986

36. Zawadzki JK, Wolfe RR, Mott DM, Lillioja S, Howard BV, Bogardus C: Increased rate of Cori cycle in obese subjects with NIDDM and effect of weight reduction. Diabetes 37:154-159, 1988

37. Ohlson LO, Larsson B, Bjorntorp P, Eriksson H, Svardsudd K, Welin L,
Tibblin G, Wilhelmsen L: Risk factors for type 2 (non-insulin-dependent) diabetes mellitus: thirteen and one-half years of follow-up of the participants in a study of Swedish men born in 1913. Diabetologia 31:798-805, 1988

38. Holman GD, Kozka IJ, Clark AE, Flower CJ, Saltis J, Habberfield AD, Simpson IA, Cushman SW: Cell surface labeling of glucose transporter isoform GLUT4 by bis-mannose photolabel: correlation with stimulation of glucose transport in rat adipose cells by insulin and phorbol ester. $J$ Biol Chem 265:18172-18179, 1990

39. Karlsson HK, Zierath JR: Insulin signaling and glucose transport in insulin resistant human skeletal muscle. Cell Biochem Biophys 48:103-113, 2007

40. Krook A, Bjornholm M, Galuska D, Jiang XJ, Fahlman R, Myers MG Jr, Wallberg-Henriksson H, Zierath JR: Characterization of signal transduction and glucose transport in skeletal muscle from type 2 diabetic patients. Diabetes 49:284-292, 2000

41. Cohen P, Alessi DR, Cross DA: PDK1, one of the missing links in insulin signal transduction? FEBS Lett 410:3-10, 1997

42. McManus EJ, Sakamoto K, Armit LJ, Ronaldson L, Shpiro N, Marquez R, Alessi DR: Role that phosphorylation of GSK3 plays in insulin and Wnt signalling defined by knockin analysis. EMBO J 24:1571-1583, 2005

43. Hu Z, Dai Y, Prentki M, Chohnan S, Lane MD: A role for hypothalamic malonyl-CoA in the control of food intake. J Biol Chem 280:39681-39683, 2005

44. Kraegen EW, Saha AK, Preston E, Wilks D, Hoy AJ, Cooney GJ, Ruderman NB: Increased malonyl-CoA and diacylglycerol content and reduced AMPK activity accompany insulin resistance induced by glucose infusion in muscle and liver of rats. Am J Physiol Endocrinol Metab 290:E471-E479, 2006

45. Morino K, Petersen KF, Shulman GI: Molecular mechanisms of insulin resistance in humans and their potential links with mitochondrial dysfunction. Diabetes 55 (Suppl 2):S9-S15, 2006 